\title{
ANALISIS PENDIDIKAN KARAKTER PONDOK PESANTREN HAMZANWADI NAHDATUL WATHAN (NW) PANCOR
}

\author{
Badrun \\ Fakultas Tarbiyah dan Keguruan, Universitas Islam Negeri Mataram \\ email korespondensi: badrunm1962@gmail.com.
}

\begin{abstract}
Indonesia is still experiencing a crisis of morality marked by the rise of murder, robbery, corruption, collusion, nepotism. Neither are problems in the world of education still many brawls of school children, promiscuity, drug abuse, etc. Social or moral damage that occurs shows the need for improvement in terms of character education early on through education. The role of Islamic boarding schools especially Hamzanwadi Islamic Boarding School NW Pancor is very much needed in improving the nation's morality through character education with high religious power. This research is a qualitative research with a case study in Islamic Boarding School Hamzanwadi NW Pancor through interviews, in-depth discussion, and observation. The analysis shows that the source of values, types of values and indicators of character education in Islamic boarding schools will be realized with the existence of synergy. The synergy that must be carried out is the role of the Teachers, Ustad, parents and the community in developing and developing character education in the Hamzanwadi Islamic Boarding School NW Pancor. This research is expected to be used as a reference, reference, or comparison in character education and can contribute to the development of character education literacy in Indonesia.
\end{abstract}

Keywords: education, character, synergy

\begin{abstract}
Abstrak: Indonesia masih mengalami krisis moralitas yang ditandai dengan maraknya pembunuhan, perampokan, korupsi, kolusi, nepotisme. Begitupula masalah di dunia pendidikan masih banyak terjadi tawuran anak sekolah, pergaulan bebas, penyalahgunaan narkoba dll. Kerusakan sosial atau moral yang terjadi menunjukan perlunya pembenahan dari sisi pendidikan karakter sejak dini melalui pendidikan. Peran Pondok Pesantren khususnya Pondok Pesantren Hamzanwadi NW Pancor sangat diperlukan dalam pembenahan moralitas Bangsa melalui Pendidikan Karakter dengan kekuatan religiusitas yang tinggi. Penelitian ini adalah penelitian kualitatif dengan studi kasus di Pondok Pesantren Hamzanwadi NW Pancor melalui wawancara, diskusi mendalam, dan observasi. Hasil analisis menunjukkan bahwa sumber nilai, jenis-jenis nilai dan indikator pendidikan karakter di Pondok Pesantren akan terwujud dengan adanya sinergisitas. Sinergisitas yang harus dilakuakn adalah adanya peran Tuan Guru, ustad, orang tua dan masyarakat dalam membangun dan mengembangkan pendidikan karakter di Pondok Pesantren Hamzanwadi NW Pancor. Penelitian ini diharapkan dapat dijadikan sebagai rujukan, acuan, atau perbandingan dalam Pendidikan karakater dan bisa berkontribusi dalam pengembangan literasi Pendidikan karakter di Indonesia.
\end{abstract}

Kata kunci: pendidikan, karakter, sinergisitas 


\section{PENDAHULUAN}

Proses peningkatan kualitas pendidikan di Indonesia telah dilakukan dengan upaya menyeluruh. Aspek dominasi hasil pendidikan dalam beberapa tahun terakhir adalah IQ (intelligence quotient). Sementara, implementasi karakter pendidikan secara tepat sangat penting. Situasi terkini di Indonesia, meningkatnya masalah kejahatan anak muda, tawuran, perkelahian dan intimidasi menyebabkan pendidikan karakter sangat penting. Upaya maksimal dalam proses mengembangkan dan memajukan pendidikan Nasional dilakukan dalam proses pengembangan pendidikan berkelanjutan dalam mewujudkan persaingan global.

Proses dan hasil pendidikan dapat menentukan kualitas sumber daya manusia seperti yang dilaporkan oleh Hidayat \& Patras (2013). Sumber daya manusia yang berkualitas tinggi ditentukan oleh proses dan implementasi pendidikan yang diharapkan. Upaya membangun pendidikan karakter juga dilakukan dengan membuat kantin yang jujur, kantin kejujuran ini gagal diimplementasikan karena sebagian besar siswa tidak jujur. Oleh karena itu pendidikan karakter harus dibangun dengan contoh-contoh menggabungkan sikap dan perilaku yang sesuai dengan usia mereka. Hal ini dapat dilakukan dengan kepatuhan siswa pada peraturan sekolah, proses pembelajaran dan kegiatan ekstrakurikuler (Gurning \& Laura, 2014; Andayati, 2012; Santosa, 2010).

Peningkatan kapasitas siswa untuk mengidentifikasi baik dan buruk dalam kondisi aktual adalah tujuan dari pendidikan karakter (Salahudin, 2013). Efek implementasi di lembaga pendidikan belum sepenuhnya membuktikan keberhasilan dan karakter pengetahuan. (Agboola \& tsai, 2012; Kamaruddin, 2012). Pendidikan karakter yang tidak memadai disebabkan oleh manajemen sekolah yang buruk. Tambahan masalah pendidikan karakter di sekolah dikarenakan tidak memiliki contoh, terutama contoh atau teladan dari guru (Triatmanto, 2010; Adawiah, 2016). 
Kisby (2017) telah menjelaskan bahwa pandangan terhadap pendidikan karakter secara sempit berkaitan dengan prilaku moral individu yang diekspresikan dalam kehidupannya dan dia menyarankan bahwa fokus pendidikan karakter terletak pada etika pribadi daripada etika publik. begitu pula Walsh (2018) telah melaporkan bahwa pendukung pendidikan karakter mengakui bahwa kontek sosial sangat penting tetapi mereka menyimpulkan bahwa lebih mudah merubah individu daripada merubah masyarakat. Winton (2008) memberikan komentar bahwa fokus pendidikan karakter pada individu yang akan membuat institusi budaya, ekonomi dan politik yang hebat dan melanggengkan status quo.

Pendidikan karakter seperti yang digagas oleh Bull \& Allen, (2018) dan Taylor (2018) memberikan gagasan bahwa pendidikan karakter berfokus pada karakter individu yang dipengaruhi oleh bacaannya dan pendidikan karakter melayani agenda sosial yang bersifat konservatif dan liberal secara ekonomi. Boyd (2010) memberikan kritik terhadap program pendidikan karakter dengan menyatakan bahwa sebagaian besar literatur tentang pendidikan karakter yang sangat konservatif secara konseptual, empiris, moral, politik dan menyimpang secara Pendidikan.

Walsh (2018) telah mengklaim bahwa fokus karakter sebagai dasar untuk pertumbuhan manusia dan masyarakat. Pendidikan karakter memiliki peran struktur dalam sosial, politik dan ekonomi. sementara Kisby (2017) telah berpendapat bahwa pendukung pendidikan karakter memberikan kegagalan dalam membedakan antara orang baik dan warga negara yang baik. Judith Suissa (2015) telah menaganalisis kebangkitan pendidikan karakter di Inggris dengan menghilangkan pengaruh politik. program pendidikan karakter telah menggantikan ide politik melalui pendekatan dan bahasa mereka.

Krisis moralitas masih menjadi tugas dunia Pendidikan saat ini. Peran pondok pesantren sangat penting dalam membentuk dan mengembangkan Pendidikan karakter di Indonesia. Mengingat umur ponpes di Indonesia sudah lama bahkan sebelum Indonesia merdeka. 
Penelitian ini bertujuan untuk menganalisis sumber-sumber nilai, jenisjenis nilai, indikator dan sinergisitas pendidikan karakter di Ponpes Hamzanwadi NW Pancor.

\section{METODE}

Penelitian ini adalah penelitian kualitatif dengan studi kasus bertempat di Pondok Pesantren Hamzanwati NW Pancor yang merupakan Pusat Pondok Pesantren Nahdatul Wathan (NW) di Indonesia. Penelitian ini menginvestigasi pendidikan karakter yang dikembangkan dengan fokus pada Sumber nilai, jenis nilai dan indikator nilai pendidikan karakter di Ponpes Hamzanwadi NW Pancor. Kegiatan penelitian ini menekankan pada aspek peristiwa, aktivitas-aktivitas, dan proses dalam pendidikan karakter yang dilakukan oleh individu ataupun kelompok (Gall et al. 2003). Teknik pengumpulan data dilakukan dengan wawancara, observasi, diskusi mendalam dan dokumentasi. Penelitia ini menggunakan wawancara dan diskusi mendalam dengan tatap muka dengan para Tuan Guru, Ustad dll. data dikumpulkan dan dianalisis secara spesifik kemudian ditarik kesimpulan. Secara umum, data dianalisis dengan model interaktif. Permulaan dengan proses pengumpulan data kemudian disimpulkan, dikodekan, dibuat dalam bentuk katagori, diilustrasikan dalam matrik, dilakukan simpulan dan verifikasi. verifikasi data dilakukan dengan penjabaran berdasarkan temuan yang ada (Miles et al. 2014).

\section{HASIL}

Pondok Pesantren Hamzanwadi berorienatasi untuk menghasilkan generasi baru yang memiliki keunggulan dalam menghadapi tantangan global. Visi Pondok Pesantren Hamzanwadi adalah “ membentuk Insan yang unggul dalam menguasai tradisi ulama salaf saleh, baik di bidang ilmiah maupun amaliah serta mampu melahirkan generasi 'khairul ummah' tafaqquh fi ad--ddin." Visi di atas menggambarkan fokus Pondok Pesantren Hamzanwadi dalam bidang pendidikan. Sementara itu, Misi Pondok Pesantren Hamzanwadi adalah: (a) Menyelenggarakan pusat 
studi buku Islam Ahlussunah Wal jamaah ala mazhab imam Syafi'i; (2) Menyelenggarakan studi ilmu-ilmu Islam klasik secara mendalam dan menyeluruh melalui sistem pondok pesantren salafi; (3) Melakukan kaderisasi calon ahli fiqih yang dapat mengembangkan tradisi ilmiah dan amaliah sesuai tuntutan zaman.

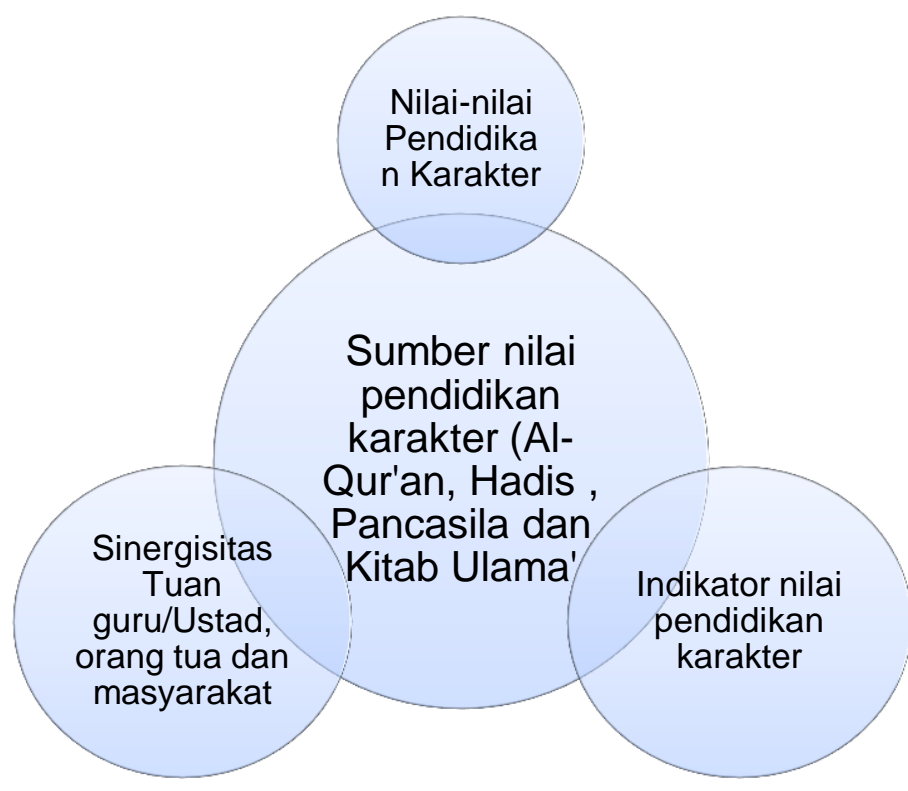

Gambar 1. Diagram Konsep Pendidikan karakter di Ponpes Hamzanwadi NW Pancor

Gambar 1. Menunjukkan Konsep pendidikan karakter yang dikembangkan di Ponpes Hamzanwadi NW Pancor merupakan konsep nilai pendidikan karakter yang berkaitan dengan entitas karakter yang mencakup aspek pengetahuan, sikap dan kepribadian dan dapat dikelompokkan dalam beberapa dimensi. Dimensi karakter yang dikembangkan di Ponpes Hamzanwadi NW Pancor meliputi: Pertama, Sumber nilai pendidikan karakter yang dikembangkan yaitu (Al-Qur'an, Hadis, Pancasila dan Kitab Para Ulama'). Kedua Nilai-nilai pendidikan karakter yang dikembangkan. Ketiga Indikator nilai Pendidikan karakter yang dikembangkan. Keempat, sinergisitas peran Tuan guru/ustad, orang tua dan masyarakat. 


\section{a. Sumber Nilai Pendidikan Karakter Yang Dikembangkan}

Al-qur'an merupakan sumber nilai pendidikan karakter yang dikembangkan di Ponpes Hamzanwadi NW Pancor. Berdasarkan wawancara mendalam dan diskusi dengan Tuan Guru Muchsan Yunus, Lc. (pengajar pada Ma'had), Tuan Guru Muhtar, Tuan Guru Drs. H. Mustamiuddin, SH, dan Tuan Guru Hasanain Juwaini, Lc. Peneliti mendapatkan informasi bahwa pendiri Pondok Pesantren Hamzanwadi NW Pancor, yaitu Tuan Guru H. Mohammad Zaenuddin Abdul Majid, telah menulis kumpulan syair-syair dalam buku "Wasiat Renungan Masa," yang menunjukkan bahwa Al-qur'an sebagai sumber nilai Pendidikan karakter antara lain memuat bait-bati berikut:

Negara kita berpancasila

Berketuhanan Yang Maha Esa

Umat Islam paling setia

Tegakkan sila yang paling utama

Yang Maha Esa adalah satu

Mustahil berbilang mustahil berpadu

Dengan dalil Qur'an yang satu

Surah Al-Ikhlash tempatnya jitu

Sumber nilai pendidikan karakter yang kedua sebagai pedoman dalam pengembangan karakter pada Pondok Pesantren Hamzanwadi NW Pancor adalah Hadis Nabi Muhammad SAW. Berdasarkan hasil wawancara mendalam dan diskusi dengan beberapa Tuan Guru, seperti Tuan Guru Haji Muchsan Yunus, Lc., Tuan Guru Muhtar, dan Tuan Guru Drs. H. Mustamiuddin, SH, peneliti memiliki kesimpulan bahwa ketiga Tuan Guru tersebut memiliki pandangan yang sama tentang pentingnya hadis-hadis Nabi Muhammad sebagai sumber nilai dalam pengembangan pendidikan karakter. Hadis-hadis yang dijadikan sebagai sumber nilai dalam pengembangan pendidikan karakter dinyatakan oleh tiga Tuan Guru sebagai berikut:

"Hadis-hadis Rasullullah yang berkaitan dengan pendidikan karakter (akhlak) seperti: (1) hadis dari HR. Ar-Ridha yang artinya paling dekat dengan Aku kedudukannya pada hari kiamat adalah orang yang 
paling baik akhlaknya dan sebaik-baik kamu ialah yang paling baik terhadap keluarganya, (2) Rasulullah bersabda : sesungguhnya seorang mukmin karena kebaikan akhlaknya menyamai derajat orang yang biasa melakukan saum dan menunaikan shalat malam (HR. Abu Daud), (3) Rasulullah saw bersabda Tidak ada sesuatu yang lebih berat dalam timbangan seorang mukmin pada hari kiamat nanti selain akhlak mulia. (4) sesungguhnya Allah membenci orang yang berbuat keji dan berkata-kata keji (HR. At-Tirmizi), (5) dari Abu Jabir ra Rasulullah saw bersabda sesungguhnya yang paling aku cintai dari kalian dan yang paling dekat tempatnya dari-Ku dihari kiyamat adalah yang paling mulia akhlaknya,dan yang paling aku benci dari kalian dan yang paling jauh tempatnya dari-Ku di hari kiyamat adalah yang banyak bicara, angkuh dalam berbicara, dan sombong (Sunan Abu Daud dan at-Tirmizi: Shahih) dan (6) seorang muslim adalah saudara bagi muslim lainnya, ia tidak menzhaliminya dan tidak merendahkannya. taqwa itu di sini (beliau menunjuk ke dadanya 3 kali), cukuplah seorang dikatakan jahat jika dia menghinakan saudaranya sesama muslim. Setiap muslim dengan muslim lainnya adalah haram darahnya, hartanya dan kehormatannya (HR.Muslim)"

Tuan Guru H. Mohammad Zaenuddin Abdul Majid telah menulis bait-bait dalam kumpulan syair berjudul "Wasiat Renungan Masa" terkait sumber nilai dari hadis antara lain sebagai berikut:

Qur'an hadis landasan kita

Bukan petunjuk bake' belate

Ataupun ceceta ramalan belaka

I'tiqad suci harus dijaga

Nabi sembahyang setelah hijrah

Bersama Yahudi ke satu arah

Akhirnya Tuhan turunkan perintah

Harus Kembali Menghadap Ka'bah

Disaat' nakku dimedan juang

Qur'an Hadist tetaplah pegang

ljma', qias jangan dibuang

Seperti sirih peluang kegagang

Karena setia menjunjung perintah

Menghidupkan Qur'an menghidupkan Sunnah

Banyak terhulur butiran hikmah

Falhamdulillah wasysyukrulah" 
Sumber lain yang menjadi dasar pengembangan pendidikan karakter di Pondok Pesantern Hamzanwadi NW Pancor adalah kitab para ulama' terkenal. Berdasarkan hasil wawancara dan diskusi mendalam dengan Tuan Guru Muchsan Yunus Lc. peneliti mendapatkan informasi bahwa kitab-kitab para ulama terkenal menjadi sumber dalam pengembangan pendidikan karakter, sepeti dinyatakan berikut:

"Kitab-kitab yang menjadi sumber nilai dalam pengembangan pendidikan karakter (akhlak) pada pondok pesantren Hamzanwadi NW Pancor adalah: (1) pernyataan Imam Abu Hanifah (pendiri mazhab Hanafi) beliau berkata "jika tidak karena dua tahun, Nu'man telah celaka. Karena dua tahun saya bersama sayyidina Imam Jaffar as-Shadiq, maka saya mendapat ilmu spiritual yang membuat saya lebih mengetahui jalan yang benar (kitab Durr al-Mantsur), (2) Imam Maliki (Pendiri mazhab Maliki) berkata barang siapa mempelajari/mengamalkan tasawuf tanpa fikih maka dia telah zindiq, dan barang siapa telah mempelajari fiqih tanpa tasawuf dia tersesat, dan siapa yang mempelajari tasawuf dengan disertai fiqih dia meraih kebenaran (Ali al-Adawi dalam kitab ulama fikih, juz 2 hal 195 yang diriwayatkan dari Imam Abu Hasan), (3) Imam syafi'i mengungkapkan saya berkumpul dengan orang-orang sufi dan menerima tiga ilmu: mereka mengajariku bagaimana berbicara, mereka mengajariku bagaimana memperlakukan orang lain dengan kasih sayang dan kelembutan hati, mereka membimbingku ke dalam jalan tasawuf (riwayat dari Kitab al-Kasf al-Khafa dan Muzid al-Albas, Imam Ajluni juz 1 hal 341), (4) Imam Ahmad bin Hanbal pendiri mazhab Hambali berkata "anak-ku kamu harus duduk bersama orang-orang sufi,karena mereka adalah mata air ilmu dan mereka selalu mengingat Allah dalam hati mereka. Mereka adalah orangorang zuhud yang memiliki kekuatan spiritual yang tinggi. Aku tidak melihat orang yang lebih baik dari mereka.(Ghiza al-Al-bab, juz 1 hal 120;Tanwir al-Qulub (hal. 405); syekh Amin Al-Qurdi), (5) Imam al-Ghazali dalam kitab Al-Arba'in Fi Ushul al-Din, memberikan solusi pemecahan dengan konsep perbaikan akhlaknya, menurut beliau akhlak yang baik itu dapat dicapai dengan cara menghilangkan semua kebisaan buruk yang telah diterangkan dengan jelas satu persatu oleh syariat. Menjauhkn diri dari padanya dengan membencinya sebagaimana seseorang itu menjauhkan diri dari pada segala macam benda kotor disamping ia berusaha dengan bersungguh-sungguh membiasakan kebiasaan yang baik sehingga memberi kesan kepada jiwanya dan kemudian barulah dia merasakan nikmat dan kesenangan dari pada hasil usahanya itu. Konsep pendidikan akhlak menurut Imam Gazali adalah dengan membersihkan dan mensucikan kalbu dari segala hal yang tidak disukai oleh Allah swt. dan merias diri dengan segala hal yang dicintai oleh Allah dengan jalan mujahadah dan riyadhah melalui fase-fase sebagi berikut yaitu fase pertama membersihkan atau menjernihkan hati dari akhlak tercela yang 
mencakup 10 (sepuluh) sifat tercela yang satu dengan yang lainnya saling berkaitan, yang meliputi: nafsu makan yang rakus, berbicara kotor, amarah, kedengkian, bakhil dan cinta dunia, ambisi dan gila harta, takabur, takjub diri dan riya', fase ke dua adalah merias atau menghias hati dengan segala akhlak mulia yang mencakup sepuluh sikap mulia satu dengan yang lainnya juga saling berkaitan yang meliputi; taubat, khauf, zuhud, sabar, syukur, ikhlas dan jujur, tawakal, cinta, ridha terhadap qadha' dan mengingat mati dan hakikat serta ragam siksa ruhani”

\section{b. Jenis-Jenis Nilai Pendidikan Karakter Yang Dikembangkan}

Sumber nilai pengembangan pendidikan karakter pada pondok pesantren Hamzanwadi NW Pancor adalah Alquran, Hadist dan Kitab para Ulama'. Nilai karakter yang dikembangkan adalah nilai karakter yang terkandung dalam sumber-sumber tersebut. Peneliti melakukan wawancara dengan beberapa Tuan Guru, seperti Tuan Guru Drs. H. Mustamiuddin, SH, Tuan Guru H. Muchsan Yunus LC, Tuan Guru H. Muhtar dan Tuan Guru Drs. H. Hasanaen tentang nilai karakter yang dikembangkan. Mereka menyatakan:

"Jenis-jenis nilai pendidikan karakter (akhlak) yang dikembangkan yang bersumber dari Alquran adalah: (1) keteladanan, (2) berbuat baik khususnya pada ibu bapak, (3) kasih sayang, (4) bersyukur, (5) berbuat baik dan berlaku adil (6) berkorban (7) patuh pada hukum, (8) kerja keras dan (9) tolong menolong. Selanjutnya jenis-jenis nilai karakter yang dikembangkan dan dilarang yang bersumber dari Hadis-hadis Rasullullah adalah sebagai berikut: (1) nilai yang dikembangkan, yaitu akhlak mulia, jujur dan kebersamaan, dan (2) nilai yang dilarang mencakup sifat angkuh dalam berbicara, sombong, berlaku dusta, hasad dan saling membenci. Adapun jenis-jenis nilai yang berasal dari kitab para ulama yang meliputi: (1) nilai yang perlu dikembangkan yaitu nilai kebenaran, kasih sayang, akhlak yang baik, kerja keras, akhlak mulia yang mencakup taubat, khauf, zuhud, sabar, syukur, ikhlas, jujur, tawakal, cinta, ridha terhadap qadha' dan mengingat mati dan hakikat serta ragam siksa ruhani, dan (2) nilai yang dilarang nafsu makan yang rakus, berbicara kotor, amarah, kedengkian, bakhil dan cinta dunia, ambisi dan gila harta, cinta dunia, takabur, takjub diri dan riya' "“

\section{c. Indikator Pengembangan Nilai Pendidikan Karakter}

Sumber nilai (Al-qur'an, Hadis dan kitab para ulama) merupakan rujukan dan pedoman utama Pondok Pesantren Hamzanwadi NW Pancor 
dalam penyelenggaraan pendidikan. Dalam hal ini, pendidikan karakter merupakan bagian integral dari komponen-komponen pendidikan Pondok Pesantren Hamzanwadi NW Pancor. Oleh karena itu, pendidikan karakter menjadi indikator penting dalam proses pendidikan santri. Tuan Guru $\mathrm{H}$. Muchsan Yunus Lc. menggungkapkan tentang indikator pengembangan pendidikan karakter sebagai berikut:

"Tuan Guru pada Pondok Pesantren Hamzanwadi NW Pancor tidak mengungkapkan secara rinci indikator dari masing-masing jenis nilai karakter. Namun demikian, dalam pengungkapannya dinyatakan bahwa indikator yang dapat dilihat secara mudah dalam implementasi dari pengembangan pendidikan karakter: (1) ketaatan dan ketepatan waktu para santri dalam melaksanakan shalat berjama'ah setiap shalat wajib, (2) kedisiplinan atau kepatuhan serta ketaatan para santri dalam mengikuti aturan yang telah ditetapkan oleh pondok pesantren, (3) kerja keras para santri dalam belajar dan menuntut ilmu, (4) sikap dan prilaku santri yang sopan dan santu dalam berkomunikasi, dan (5) sabar, ikhlas dan istiqamah dalam menuntut ilmu"

\section{d. Sinergisitas Pendidikan Karakter}

Sinergisitas Pendidikan karakter dipondok pesantren Hamzanwadi Pancor dilakukan dengan melibatkan Tuan Guru/Ustad, Orang tua dan masyarakat. Tuan Guru atau ustad di pondok pesantren menjadi contoh atau teladan dalam sikap dan perilaku di pondok pesantren. Perilaku atau sikap mereka mencerminkan konsep yang ada. Para Tuan Guru atau ustad selama preses pembelajaran atau keseharian di pondok harus terus-menerus memastikan setiap aktivitas siswa atau santri dalam membentuk dan mengembangkan pendidikan karakter. adanya pemberian reward dan panishment menjadi kontrol bagi santri dalam pendidikan karakter. Santri atau siswa dipastikan menerapkan sikap ketekunan, jujur, keadilan, tanggung jawab, menghargai diri dan sesama sehingga menjadi sebuah kebiasaan. 
Peran orang tua dalam membentuk dan mengembangkan Pendidikan karakter sangat diperlukan. Keterlibatan orang tua ditandai dengan adanya buku kontrol atau evaluasi untuk santri. Evaluasi Pendidikan karakter diperlukan sebagai acuan orang tua menilai sejauh mana aplikasi pendidikan karakter selama beraktivitas keseharian di rumah. Aktivitas keseharian baik berupa sholat, puasa, sholat tahajud, membantu orang tua dll. Adapun peran masyarakat juga sangat diperlukan bagi Pondok Pesantren dalam mengevaluasi Pendidikan karakter. Menumbuhkan karakter keagamaan dilakukan dengan bentuk kegiatan pembacaan Do'a (Hiziban) tiap-tiap kampung. Menumbukan karakter sosial seperti bansos dengan membagi sembako kepada korban gempa bumi, longsor, banjir dll begitupula dengan kegiatan pembagian zakat, infaq, dan shodaqoh ditengah masyarakat.

\section{PEMBAHASAN}

Al-qur'an sebagai sumber nilai dalam Pendidikan karakter di Pondok Pesantren Hamzanwadi NW Pancor ditujukkan dalam bait-bait syair Renungan masa. Nilai yang terkandung bukan saja sekedar "Nilai Tauhid" tetapi nilai Pancasila, syari'ah dan mu'amalah yang dibutuhkan dalam kehidupan umat Islam pada setiap masa. Terdapat 7 (tujuh) surah dan 13 ayat yang dijadikan sebagai sumber nilai pendidikan karakter di pondok pesantren Hamzanwadi NW Pancor. Hal ini tidak berarti mengabaikan surah-surah dan ayat-ayat yang lain, tetapi lebih merupakan pilihan prioritas dalam pengembangan nilai-nilai karakter.

Hadis-hadis Rasullullah yang dikemukakan oleh sumber penelitian menggambarkan keutamaan nilai-nilai akhlak mulia sebagai sumber nilai moral dalam pendidikan karakter. Jenis nilai karakter yang disebutkan secara jelas, seperti nilai kejujuran, memiliki makna pendidikan. Nilai kejujuran dapat menjadi instrumen pendidikan moral yang berdimensi vertikal yang erat kaitannya dengan ibadah wajib dan sunnah kepada Allah, dan berdimensi horizontal yang erat kaitannya dengan sikap 
amanah dan tanggung jawab. Jenis-jenis nilai karakter yang terungkap dari beberapa hadis tersebut di atas tidak hanya merupakan jenis-jenis nilai karakter yang bermakna baik, tetapi juga jenis-jenis nilai yang bermakna tidak baik (larangan), seperti dengki, keji, sombong dan lain lain. Nilai-nilai yang tidak baik harus dijauhi.

Kitab para ulama terkenal di atas memberikan tuntunan secara jelas tentang nilai karakter dan tahapannya dalam proses pendidikan. Dalam pengembangan pendidikan karakter, Pondok Pesantren Hamzanwadi NW Pancor mengambil substansi dari kitab dan pendapat para Ulama' yang telah disebutkan di atas. Kitab-kitab para ulama yang menjadi sumber dalam pengembangan pendidikan karakter sangat dibutuhkan oleh Pondok Pesantren Hamzanwadi NW Pancor. Kitab-kitab yang disebutkan menunjukkan bahwa pengembangan pendidikan karakter di Pondok Pesantren Hamzanwadi NW Pancor telah memiliki referensi akademik yang cukup lengkap dengan nilai akademik yang tinggi dalam pengembangan pendidikan karakter. Hal ini menjelaskan bahwa substansi dari nilai karakter yang dikembangkan di Pondok Pesantren Hamzanwadi NW Pancor adalah nilai-nilai luhur yang merupakan nilai mulia dalam kehidupan manusia.

Sumber-sumber nilai dalam mengembangkan Pendidikan karakter di Pondok Pesantren Hamzanwadi Pancor sesuai dengan penelitian yang telah dilakukan oleh Pearson (2016) dan Zurqoni et al. (2018) bahwa tujuan utama pendidikan di Ponpes atau sekolah adalah bagaimana menjamin proses pendidikan sesuai dengan sumber nilai dan jenis nilainilai yang diadopsi oleh satuan pendidikan, komunitas tertentu, dapat diadopsi dengan baik. pada saat yang sama sumber nilai dan jenis nilai pendidikan karakter berfungsi sebagai pedoman untuk menentukan keberhasilan proses pendidikan di sekolah atau pondok pesantren. Selain sumber nilai yang harus jelas, Kesuksesan pendidikan karakter harus didukung oleh beberapa komponen pada implementasinya. 
Ada tiga komponen pendukung yang harus disiapkan oleh sekolah atau Pondok Pesantren yaitu: Staf Pengajar yang unggul, kurikulum khusus dan sistem nilai karakter yang dikembangkan. staf pengajar yang kompeten atau Ustad (Tuan Guru) merupakan penentu keberhasilan pendidikan karakter, karena mereka para ustad atau Tuan Guru sebagai suritauladan atau contoh nyata dalam pendidikan karakter. (Ulger et al. 2014), begitupula kurikulum khusus atau unggulan yang diterapkan di sekolah atau Pondok Pesantren menentukan kesuksesan pendidikan karakter yang diharapkan (Fahmy et al. 2015; Barghi et al. 2017).

Pondok Pesantren merumuskan strategi untuk mencapai nilai-nilai pendidikan karakter. strategi yang dilakukan adalah mengarahkan staf tenaga pengajar atau ustad dengan orang tua siswa berkalaborasi dan berkomitmen untuk terlibat dalam semua program yang dapat mencapai nilai-nilai pendidikan karakter yang dicanagkan. Begitupula strategi merupakan proses penggabungan Visi Misi sekolah atau Pondok Pesantren, Kebijakan dan kegiatan yang menjadi satu kesatuan untuk tercapainya Nilai-nilai pendidikan karakter (Greer, 2001).

Jenis-jenis nilai pendidikan karakter yang dikembangkan di Pondok Pesantren Hamzanwadi NW Pancor adalah nilai-nilai karakter yang bersumber dari Al-qur'an, Hadis dan kitab para Ulama'. Oleh karena itu, karakter atau kepribadian yang dikembangkan di Pondok Pesantren Hamzanwadi NW Pancor meliputi ciri-ciri sebagai berikut: (1) memiliki ilmu yang tinggi, (2) suka beramal, (3) taqwa, (4) berakhlaqul karimah, (5) berbudaya, (6) bermoral, dan (7) memiliki tanggung jawab terhadap masa depan bangsa dan negara Indonesia. Ciri-ciri kepribadian atau karakter yang dikembangkan di Pondok Pesantren Hamzanwadi NW Pancor sesuai dengan tujuan pendidikan karakter dalam Sistem Pendidikan Nasional, yaitu karakter bangsa yang bersumber dari nilai-nilai "Pancasila."

Indikator yang diungkapkan oleh Tuan Guru merupakan refleksi dari pemahaman para santri tentang jenis-jenis nilai pendidikan karakter 
yang diperoleh dari Tuan Guru dan para ustadz. Dalam hal ini, para santri tidak hanya mengetahui jenis-jenis nilai pendidikan karakter sebagai ilmu pengetahuan, tetapi juga dipahami sampai pada tingkat pemahaman dan afeksi yang ditunjukkan dalam kehidupan dan prilaku para santri. Kondisi ini tidak mudah dicapai, tetapi membutuhkan proses yang konsisten dan terus menerus dari semua elemen pengelola yang ada di pondok pesantren dalam memberikan keteladanan. Indikator pengembangan pendidikan karakter yang secara normatif diungkapkan oleh Tuan Guru di atas merupakan bentuk operasional dari pendidikan karakter di Pondok Pesantren Hamzanwadi NW Pancor. Indikator lain yang dapat menggambarkan pengembangan pendidikan karakter secari formal adalah nilai yang ada pada mata pelajaran pendidikan karakter (akhlak) pada Pondok Pesantren Hamzanwadi NW Pancor.

Pendidikan karakter dilakukan di Ponpes NW Pancor dan diperkuat dengan manajemen sekolah yang baik. indikator yang sangat penting dalam pendidikan karakter adalah meningkatnya religuisitas, moralitas dan kepemimpinan anak didik di Ponpes. tingkat religiositas adalah indikator yang paling nampak dalam pendidikan karakter di Ponpes atau sekolah (Arthur, 2019). Pembentukan karakter siswa atau santri dapat dilakukan melalui proses pembelajaran, standar proses, standar isi, dan standar penilaian harus terpenuhi dalam proses pembelajaran. tujuannya adalah agar proses pembelajaran nilai-nilai pendidikan karakter diharapkan dapat tercapai. proses pembelajaran di Pondok pesantren Hamzanwadi NW Pancor sudah memenuhi semua standar untuk pendidikan karakter yang diharapkan.

Tujuan Pendidikan karakter di pondok pesantren adalah membentuk akhlaq yang mulia atau moralitas santri yang seutuhnya, para santri tidak hanya mendapatkan pengetahuan akademik atau intelektual yang baik juga kecerdasan emosional dan religiusitas yang tinggi. Pendidikan karakter yang mulia atau moralitas diutamakan dibandingkan dengan nilai akademik yang berbentuk angka-angka dalam rapot. Seperti 
penelitian Skaggs \& Bodenhorn (2006) telah melaporkan penelitiannya dengan bertujuan untuk mengetahui hubungan antara implementasi nilainilai pendidikan karakter pada prilaku siswa dan hasil belajar. hasil penelitian menunjukkan bahwa nilai-nilai pendidikan karakter tidak secara signifikan mempengaruhi hasil belajar atau prestasi siswa.

Upaya untuk menamkan pendidikan karakter harus dilakukan oleh tuan guru, ustad, orang tua dan masyarakat di lingkungan Pondok Pesantren atau sekolah. para ustad atau guru sangat memiliki peranan penting dalam menanamkan nilai-nilai pendidikan karakter di pondok pesantren. begitupula pondok pesantren harus memberikan atau menciptakan lingkungan yang kondusif untuk menanamkan nilai-nilai pendidikan karakter. sehingga pondok pesantren harus mengintegrasikan peran lingkungan Pesantren, Peran guru yang optimal, peran orangtua demi tercapainya tujuan pendidikan karakter yang diharapkan. begitupula peran kontrol masyarakat dan evaluasi yang terus-menerus untuk mendapatkan peningkatan nilai-nilai pendidikan karakter bagi siswa ke arah yang lebih baik.

\section{KESIMPULAN}

Pendidikan karakter yang dikembangkan di pondok pesantren Hamzanwadi NW Pancor memiliki sumber nilai dari Al-qur'an, Hadis dan Kitab Para Ulama'dan Pancasila. Sumber-sumber nilai ini merupakan inti dan pedoman dalam membentuk dan mengembangkan Pendidikan karakter. Adapun indikator yang dapat dilihat dari Pendidikan karakter adalah ketaatan dan ketepatan waktu para santri dalam melaksanakan shalat berjama'ah setiap shalat wajib, kedisiplinan atau kepatuhan serta ketaatan para santri dalam mengikuti aturan yang telah ditetapkan oleh pondok pesantren, kerja keras para santri dalam belajar dan menuntut ilmu, sikap dan prilaku santri yang sopan dan santu dalam berkomunikasi, sabar, ikhlas dan istiqamah dalam menuntut ilmu. Sinergisitas sangat 
diperlukan baik Tuan guru/Ustad, orang tua dan Masyarakat agar Pendidikan karakter berjalan dengan efektif dan efisien.

\section{DAFTAR PUSTAKA}

[1] Hidayat, R., \& Patras, Y. E. (2013). Evaluasi sistem pendidikan nasional Indonesia. ${ }^{2}$ nd International Seminar on Quality and Affordable Education (ISCAE) (pp. 235-244).

[2] Gurning, M. \& Laura, N. (2014). Implementasi pendidikan anti korupsi melalui warung kejujuran di SMP Keluarga Kudus. Jurnal Teknologi Pendidikan dan Pembelajaran, 2(1), 93-102.

[3] Andayati, D. (2012). Kantin kejujuran berbasis teknologi informasi. Jurnal Teknologi Technoscientia, 4(2), 128-136.

[4] Santosa, P. I. (2010). Prototipe kantin tanpa uang berbasis kartu pintar. JUTI, 8(1), 27-32.

[5] Salahudin, A. (2013). Pendidikan karakter. Bandung: Pusaka Setia.

[6] Agboola, A., \& Tsai, K. C. (2012). Bring character education into classroom. European Journal of Educational Research, 1(2), 163170.

[7] Kamaruddin, S. A. (2012). Character education and students social behavior, Journal of Education and Learning, 6(4), 223-230.

[8] Triatmanto, T. (2010). Tantangan implementasi pendidikan karakter di sekolah. Cakrawala Pendidikan, 29(3), 187-203.

[9] Kisby, B. (2017). Politics is ethics done in public': Exploring linkages and disjunctions between citizenship education and character education in England. Journal of Social Science Education, 16 (3), 7-20.

[10] Walsh, G. (2018). Character education and social justice. Retrieved from https://curriculumfore quity.org/2017/10/01/charactereducation-and-social-justice/ 
[11] Winton, S. (2008). The appeal(s) to character education in threatening times: Caring and critical democratic responses. Comparative Education, 44(3), 305-316.

[12] Bull, A., \& Allen, K. (2018). Introduction: Sociological interrogations of the turn to character. Sociological Research Online, 23(2), 1-7.

[13] Taylor, N. (2018). The return of character: Parallels between lateVictorian and twenty-first century discourses. Sociological Research Online, 23, 399-415.

[14] Boyd, D. (2010). Character education and citizenship education: A case of a cancerous relationship. Philosophy of Education Yearbook, 2010, 384-392.

[15] Walsh, G. (2018). Character education and social justice. Retrieved from https://curriculumfore quity.org/2017/10/01/charactereducation-and-social-justice.

[16] Suissa, J. (2015). Character education and the disappearance of the political. Ethics and Education, 10(1), 105-117.

[17] Gall, M. D., Gall, J. P. \& Borg, W. R. (2003). Educational research. Boston, MA: Pearson Education, Inc.

[18] Miles, M. B., Huberman, M. \& Saldana, J. (2014). Qualitative data analysis: A methods sourcebook. New York, NY: Sage Publication, Inc.

[19] Zurqoni, Z., Retnawati, H., Apino, E., \& Anazifa, R. D. (2018). Impact of character education implementation: A goal-free evaluation. Problem of Education in the 21th Century, 76(6), 881899. doi:10.33225/pec/18.76.881.

[20] Ulger, M. Yigittir, S. \& Ercan, O. (2014). Secondary school teachers' beliefs on character education competency. Procedia-Social and Behavioral Sciences, 131(May), 442-449. doi:10.1016/j.sbspro.2014.04.145. 
[21] Barghi, R., Zakaria, Z., Aswati, H. \& Hashim, N. H. (2017). Heritge education in the primary school standard curriculum of Malaysia. Teaching and Teacher Education, 61, 124-131. doi:10.1016/j.tate.2016.10.012.

[22] Fahmy, R., Bachtiar, N., Rahim, R., \& Malik, M. (2015). Measuring student perceptions to personal characters building in education: An Indonesian case in implementing new curriculum in high school. Procedia-Social and Behavioral Sciences, 211, 851-858, doi:10.1016/j.sbspro.2015.11.112.

[23] Greer, C. R. (2001). Strategic human resource management: A general managerial approach (2ndEdition). Upper Saddle River, NJ: Prentice Hall.

[24] Arthur, J. (2019). Christianity and the character education movement. History of Education, 48(1), 60-76. doi:10.1080/0046760X.2018.1506049

[25] Skaggs, G., \& Bodenhorn, N. (2006). Relationships between implementing character education, student behaviour, and student achievement. Journal of Advanced Academics 18(1), 333-345. doi: 10.4219/jaa-2006-345. 